\title{
Influence of Natural Climate Curing Treatment on Corrosion Activity of Reinforced Concrete
}

\author{
Ernest Ituma Egba, Norhisham Bakhary and Mohammad Ismail ${ }^{*}$
}

Faculty of Civil Engineering, UniversitiTeknologi Malaysia, Skudai - 81310, Johor, Malaysia mohammad@utm.my

\begin{abstract}
Objective: This paper explained the experimental investigation conducted on reinforced concrete specimens to ascertain the effect of natural climate curing treatment on the corrosion activity. Methods/Statistical Analysis: Concrete specimens were prepared and given different curing treatments for 28 days. Sodium chloride was added to the concrete mix to accelerate corrosion. Two sets of the specimen were moisture cured for 3 days, then, one set out of the two was exposed to the sheltered environment, and the other set to the unsheltered environment to give the concrete a natural climate curing treatment. The specimens were subjected to different exposure conditions after the curing treatments. The half-cell potential and the nominal corrosion density were measured to study the effect of the natural climate curing treatment. Findings: The results revealed variation of the reinforced concrete corrosion process due to the natural climate curing treatment. There was a rapid shift of the trend of the corrosion activity for the specimens that underwent natural climate curing treatment from the fifth month of exposure duration; the corrosion activity in the specimens became higher than the specimens that were cured normal for 28 days in water at the six months of the exposure. The finding was attributed to the high rate of temperature and rainfall fluctuation within the tropical region, which caused massive imbalance in the early stage strength development of the concrete. The high temperature cum rainfall fluctuation rate disturbed the bonding of the concrete matrix which affected the reaction of the concrete to corrosion of the reinforcing steel bar eventually. Application/Improvement: The findings could find application in reinforced concrete durability analysis.
\end{abstract}

Keywords: Corrosion Activity, Natural Climate Curing Treatment, Reinforced Concrete, Tropical Region

\section{Introduction}

The deteriorating characteristics of reinforced concrete members as a result of corrosion of rebar are a striking challenge in the building and civil engineering construction industry. The study of corrosion activity of rebar in concrete and its effects on the durability of the concrete has received the vast attention of researchers across the globe. $\mathrm{In}^{1}$ disclosed the presence of calcium carbonate and chloride ion and their reactions with rebar in concrete as the root cause of corrosion. Although the passive film on the rebar surface resulted from the alkalinity of cement matrix protects concrete against corrosion, concrete members exposed to moist environment prone to carbon dioxide and chloride ion are likely to corrode 2 .

The action of the corrosion activity of the rebar produces rust within the concrete and breeds unwanted tensile stress prior to concrete volumetric expansion ${ }^{3}$. Also, corrosion of rebar causes concrete cover cracking, concrete size, and rebar cross-sectional area reduction, including concrete, and corroding rebar bond depletion ${ }^{4}$.

Previous research indicated that the process of corrosion of rebar in concrete is influenced by numerous factors ${ }^{5}$. In ${ }^{6}$ categorized the factors that affect reinforced concrete corrosion into environmental factors, concrete cover thickness, construction quality and type of concrete structure and concrete material properties. Other factors such as concrete quality, porosity and resistivity; load type and history; and concrete crack size play significant roles in the propagation of corrosion in concrete.

Furthermore, several researchers have conducted experiments to explain the reinforced concrete corrosion and environmental factors relationship ${ }^{7-11}$. Their findings indicated that the unsteady natural environmental

*Author for correspondence 
conditions in different regions, time and seasons have varying degree of influence on the corrosion activity of reinforced concrete. $\mathrm{In}^{12}$ observed the influence of atmospheric parameters and chloride deposition rate on reinforced concrete at two cities of tropical coastal regions for two years. Concrete cubes specimen $200 \mathrm{x}$ $200 \times 200 \mathrm{~mm}$ were cast and cured in water in accordance with concrete curing specification. The specimens were exposed to seven different sites at Havana city of Cuba that has an annual temperature range of +26.1 to $+28.6^{\circ} \mathrm{C}$, an annual relative humidity range of 77.1 to $83.8 \%$ and varying chloride deposition values. The atmospheric chloride deposition rate was the only atmospheric parameter considered in the study at the exposed site of Yucatan Peninsula Mexico. It was found that the atmospheric chloride deposition influences chloride penetration in concrete.

$\mathrm{In}^{\underline{13}}$ developed a model for predicting time dependent corrosion rates of reinforcement bars based on microenvironment in concrete. The study analysed the factors responsible for the corrosion of reinforcement bars in concrete under atmospheric environment. The electrochemical fundamental model for the corrosion rate of reinforcement bars was developed based on corrosion dynamic equations. The prediction model was finally built based on the result of the electrochemical fundamental model, the result test conducted on the corrosion rate of reinforcement bars, and the resistivity of concrete under controlled climate environment. The model was proved efficient for forecasting the corrosion rate of steel bars using the micro-environment in concrete. The experimental results of ${ }^{14}$ were used to validate the model. The findings revealed that the effect of irregular fluctuations of climatic environmental conditions on the corrosion activity of reinforced concrete under natural environment must be considered in concrete durability studies.

The investigation of the influence of salinity and temperature on chloride diffusion through $150 \times 150 \times 75$ $\mathrm{mm}$ concrete cubes at twelve different locations of the world was performed by ${ }^{15}$. The twelve locations were, namely: Banyuls sur Mer - France; Cascais - Portugal; Dubai United Arab Emirates; Eastern Scheldt - Netherlands; Hirtshals - Denmark; Hvalfjordur - Iceland; Isle of the Dead - Australia; Kjopsvik - Norway; Kallahamn - Sweden; La Rochelle - France; Skanör - Sweden and Traslovslage - Sweden. The locations were categorized into cold and warm exposure locations and the period of monitoring was one year. The specimens were kept in sea water whose salinity and surface temperature were constantly measured and recorded as monthly mean values. Result showed uncertainty in the measured chloride diffusion profile. It was discovered that the temperature was the chief influencing factor in chloride diffusion into concrete.

In ${ }^{16}$ performed electrochemical tests for corrosion rate of reinforced bars with six reinforced cylindrical concrete specimens. The essence of the experiment was to investigate the influence of rapid changes of moisture content and temperature inside concrete on the corrosion rate of reinforcement bars. The specimens were exposed to the discretely changing temperature range and relative humidity range of 7 to $35^{\circ} \mathrm{C}$ and 30 to $90 \%$ respectively in the climatic and corrosion chamber. They observed that the moisture content of concrete has no significant effect on variations of corrosion rate except for situations where there is provision for quick drying of concrete saturated with water.

Natural climate concrete curing treatment within tropical region may result in sudden drying of concrete saturated with water. The implication of such and related concrete curing treatments is variant concrete properties development. The scenario that might go a long way to influence corrosion activity in reinforced concrete. Previous studies have been conducted to investigate the effect of curing treatments on the properties of concrete. $\mathrm{In}{ }^{17}$ reported high efficiency in the reduction of plastic and shrinkage strain for concrete cured in a mixture of water and acrylic-based curing compounds. $\operatorname{In}^{18}$ observed the behaviour of concrete under different curing treatments at room temperature and fixed temperature and relative humidity. They reported decrease in compressive strength as concrete moist-curing period reduces. In $\frac{19}{19}$ reported concrete compressive strengths that were very low from the ACI-318 requirements when non-standard curing treatment of water sprinkling twice a day for seven days was applied to concrete specimens in arid areas. $\operatorname{In}^{20}$ conducted a study to determine the effective curing treatment in natural climate of Saudi Arabia with an ambient temperature of more than $45^{\circ} \mathrm{C}$ and relative humidity less than $15 \%$. Their findings indicated that water sprinkling curing treatment for up to 28 days cum plastic sheet covering was the best curing treatment in the region. Nevertheless, the effect of curing treatment in natural climate on the properties of concrete is regional dependent.

In this paper, the influence of curing treatment under natural climate on the corrosion activity of reinforced concrete in the tropical region, Johor Malaysia was 
investigated. The study was needful so as to determine corrosion behaviour in naturally climate cured concrete, which is the common style of curing concrete in the society. Johor Malaysia has average rainfall and temperature of 250 centimetres and $27^{\circ} \mathrm{C}$ a year respectively. The temperature within a year ranges from $22^{\circ} \mathrm{C}$ to $34^{\circ} \mathrm{C}$ while relative humidity ranges from $70 \%$ to $90 \%$ per year.

\section{Materials and Methods}

The Ordinary Portland Cement was used to prepare the study specimen. Other materials include crushed granite of $12 \mathrm{~mm}$ maximum size, natural river sand of $5 \mathrm{~mm}$ maximum size, $12 \mathrm{~mm}$ rough surface reinforcement steel bar, Sodium Chloride $(\mathrm{NaCl})$, and clean water. The aggregates were used in a saturated surface dry condition.

Concrete with the designed mean characteristics strength of $20 \mathrm{~N} / \mathrm{mm}^{2}$, slump of 30-60 mm and 0.6 water to cement ratio was used. Figure 1 shows the typical two-dimensional line sketch of the concrete cube specimen used in the study. Sodium chloride $1 \%$ by weight of cement was added to the concrete mix for specimens B1, B2, B3, B4, $\mathrm{C} 1$, and $\mathrm{C} 2$ to accelerate corrosion of the reinforcement bar. The fresh mixed concrete was placed in moulds and compacted in layers on a vibration table. The concrete specimens were demoulded after 24 hours. Table 1 shows the

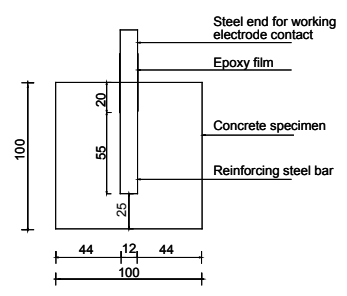

Figure 1. Typical sketch of the concrete specimen specimen notation, curing treatment, $\mathrm{NaCl}$ composition, and exposure condition of the specimen.

The specimens were kept at different exposure conditions. The half-cell potential and the Polarisation Resistance $\left(\mathrm{R}_{\mathrm{p}}\right)$ measurements were conducted on the specimen. Twenty-four specimens were used for the study.

\section{Results and Discussion}

\subsection{The Half-Cell Potential}

The half-cell corrosion potential ( $\mathrm{E}_{\text {corr }}$ ) performance of the concrete specimens as a function of time is shown in Figure 2. The high impedance voltmeter calibrated vs. the Saturated Calomel Electrode (SCE) was used for the measurement. Horizontal lines were included in Figure 2 at $-200 \mathrm{mV}$ and $-350 \mathrm{mV}$ in line with the standard for the probability of corrosion used in ASTM C 876. All the specimens had initial $E_{\text {corr }}$ in the range of -160 to -190 $\mathrm{mVvs}$ SCE, depending on the percentage of chloride in the concrete mix. The specimen with chloride content in the concrete mix indicated a higher value of initialE $E_{\text {corr }}$.

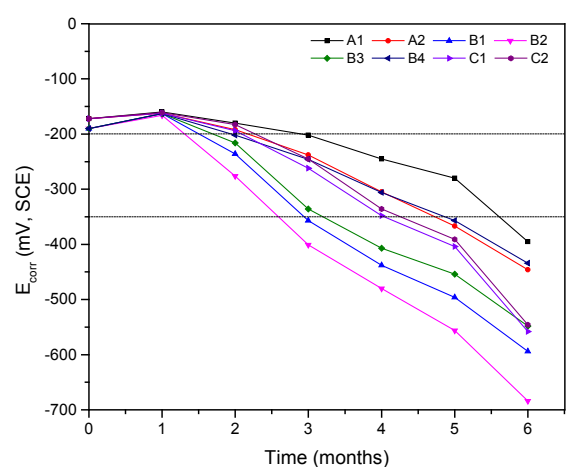

Figure 2. Corrosion potential as a function of time

Table 1. Concrete specimen curing treatment and exposure condition

\begin{tabular}{|c|c|c|c|}
\hline Specimen & Exposure Condition & $\mathrm{NaCl}$ composition & Curing Treatment \\
\hline A1 & Inside $3.5 \% \mathrm{NaCl}$ water solution after the 28 days curing. & \multirow[t]{2}{*}{ Mixed without $\mathrm{NaCl}$} & \multirow{6}{*}{$\begin{array}{l}\text { Water curing in } 3.5 \% \\
\mathrm{NaCl} \text { water solution for } \\
28 \text { days }\end{array}$} \\
\hline A2 & 7 days wet and dry cycle after the 28 days curing. & & \\
\hline B1 & Inside $3.5 \% \mathrm{NaCl}$ water solution after 28 days & \multirow{4}{*}{ Mixed with $\mathrm{NaCl}$} & \\
\hline $\mathrm{B} 2$ & 7 days wet and dry cycle after the 28 days curing. & & \\
\hline B3 & Unsheltered natural climate after the 28 days curing. & & \\
\hline B4 & Sheltered natural climate after the 28 days curing. & & \\
\hline $\mathrm{C} 1$ & $\begin{array}{l}\text { Unsheltered natural climate after the } 3 \text { days moist curing; } \\
\text { followed by } 7 \text { days wet and dry process after } 28 \text { days. }\end{array}$ & \multirow{2}{*}{ Mixed with $\mathrm{NaCl}$} & \multirow{2}{*}{$\begin{array}{l}\text { Moist curing with } 3.5 \\
\% \mathrm{NaCl} \text { water solution } \\
\text { for } 3 \text { days }\end{array}$} \\
\hline $\mathrm{C} 2$ & $\begin{array}{l}\text { Sheltered natural climate after } 3 \text { days moist curing; } \\
\text { followed by } 7 \text { days wet and dry process after } 28 \text { days. }\end{array}$ & & \\
\hline
\end{tabular}


Specimens exhibited irregular variation of $\mathrm{E}_{\text {corr }}$ with time, though in a vivid direction towards higher negative values. The B1, B2, B3, B4, C1 and C2 specimens responded faster to the corrosion potential at early stage more than the A1 and A2 specimens. The behaviour was as a result of the chloride content in the concrete mix.

However, the trend of $\mathrm{E}_{\text {corr }}$ for specimens $\mathrm{C} 1$ and $\mathrm{C} 2$ was intensified to higher negative values after about three months. This was as a result of the distorted concrete hydration process due to the natural climate curing treatment. It was observed that the $\mathrm{C} 1$ specimen maintained a higher negative value of corrosion potential more than specimen C2 throughout the study. It indicated that rainfall and sunshine intensities had effects on the corrosion activity of the reinforced concrete.

Specimen B2 responded most to corrosion attack, followed by specimens $\mathrm{B} 1$. The $\mathrm{E}_{\text {corr }}$ trend of the specimens $\mathrm{C} 1$ and $\mathrm{C} 2$ showed a steep gradient near the sixth month duration of exposure and crossed the specimen $\mathrm{B} 2 \mathrm{E}_{\text {corr }}$ trend line. The behaviour was as a result of the natural curing treatment for the $\mathrm{C} 1$ and $\mathrm{C} 2$ specimens that aggravated the corrosion process. The finding was in line with the observation of ${ }^{18}$ that curing treatment affects the behaviour of concrete. In this case, the natural curing treatment affected the concrete hydration process and led to the speedy influence of corrosion attack to the reinforcing steel in the concrete.

Specimens A1 and A2 indicated evidence of corrosion after the fifth month. The finding supports the work of ${ }^{21}$ that opined duration of five to six months for significant corrosion to be experienced in reinforced concrete samples exposed to the environment under chloride attack, providing the concrete specimen was not prepared with concrete mixed with corrosive agent. Also, the result indicated that the wet and dry cycle exposure method was the most valid technique of accelerating corrosion in reinforced concrete.

\subsection{The Corrosion Current Density}

The nominal corrosion current density ( $\mathbf{i}_{\text {corr }}$ ) behaviour of the concrete specimens as a function of time is shown in Figure 3. The nominal corrosion current density was derived from equation 1 :

$$
i_{\text {corr }}=B \times \frac{1}{R_{P}}
$$

Where $\mathrm{R}_{\mathrm{p}}$ is the polarisation resistance in $\Omega \mathrm{cm}^{2}$, and $\mathrm{B}$ is the Stern-Geary constant in V. The Stern-Geary constant

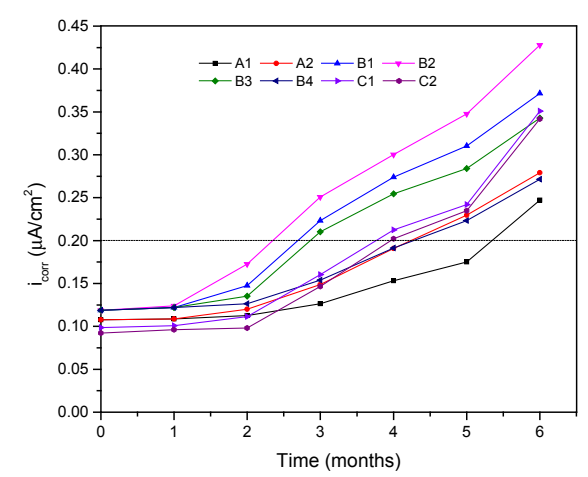

Figure 3. Nominal corrosion current density as a

was deduced through the use of the Tafel slopes of the anodic $\left(\mathbf{b}_{\mathbf{a}}\right)$ and cathodic $\left(\mathbf{b}_{\mathbf{c}}\right)$ reactions.

$$
\mathrm{B}=\frac{1}{2} .303 \times \frac{\mathrm{b}_{\mathrm{a}} \times \mathrm{b}_{\mathrm{c}}}{\left(\mathrm{b}_{\mathrm{a}}+\mathrm{b}_{\mathrm{c}}\right)}
$$

The recommended value of the Stern-Geary constant is $26 \mathrm{mV}$ for on-site measurements ${ }^{22}$.

A horizontal line at 0.2 value of the nominal corrosion current density was drawn in Figure 3 to represent the initiation time of active corrosion ${ }^{21}$. It was observed that specimens B2, B1, and B3 signalled active corrosion as the exposure duration approaches the third month. Specimens C1 and C2 indicated evidence of active carrion at the fourth month. Nevertheless, corrosion activity in the $\mathrm{C} 1$ and $\mathrm{C} 2$ specimens showed rapid acceleration from the fifth month to the sixth month. Active corrosion was initiated in specimen $\mathrm{C} 2$ before specimen B4. The performance of the nominal corrosion current density agreed with the half-cell potential measurement. The observation affirmed the assertion that natural curing treatment influences the behaviour of concrete as well as the corrosion activity of the reinforced concrete.

\section{Conclusion}

The paper discussed the investigation of the influence of curing treatment under natural climate on the corrosion activity of reinforced concrete in the tropical region, Johor Malaysia. The following inferences were drawn from the study namely:

- Curing treatment influenced active corrosion initiation period. The specimens exposed to the natural climate curing treatment exhibited a rapid response to corrosion attack as exposure duration progressed. 
- Corrosion activity in the concrete cured by natural climate treatment became higher than those that were cured for 28 days in water at the six months of the exposure.

- Natural curing treatment distorted concrete hydration process. The high rate of temperature and rainfall fluctuation within the tropical region caused massive imbalance in the early stage strength development of the concrete. It disturbed the bonding of the concrete matrix and affected the reaction of the concrete to corrosion of the reinforcing steel bar eventually.

- The sunshine and rainfall intensities at the tropical region played a significant role in the corrosion activity of reinforced concrete. The more the strength of the rainfall and sunshine, the higher the effect on corrosion activity.

- The half-cell potential measurement showed good correlation with the nominal corrosion current density performance of the reinforced concrete exposed to natural climate curing.

\section{Acknowledgements}

The authors gratefully acknowledge the support of Ministry of Higher Education Malaysia for the financial assistance, Grant no: 4F528 for this research; and the financial support received from the Research Management Centre (RMC) University Technology Malaysia (UTM), Grant no: 10H06, Faculty of Civil Engineering UTM. Also, appreciated is the support of the Management of Ebonyi State University, Abakaliki, Nigeria; the Management of Tertiary Education Trust Fund (TETFUND), Nigeria; as well as the Technicians, Faculty of Civil Engineering UTM.

\section{References}

1. Ann KY, Ahn JH, Ryou JS. The importance of chloride content at the concrete surface in assessing the time to corrosion of steel in concrete structures. Construct Build Mater. 2009; 23(1):239-45.

2. Bhattacharjee PB. Performance evaluation of rebar in chloride contaminated concrete by corrosion rate. Journal of Construction and Materials. 2009; 23(6):2346-56.

3. Bhaskar S, Bharatkumar BH, Gettu R, Neelamegam M. Effect of corrosion on the bond behaviour of OPC and PPC concrete. Journal of Structural Engineering. 2010; 37(1):37-42.

4. Shetty A, Venkataramana K, Goggi I. Performance evaluation of rebar in accelerated corrosion by gravimetric loss method. Int Journal of Earth Science and Engineering. 2012; 5(1):154-9.

5. Won SH, Hong LC, Yong AK. Factors influencing chloride transport in concrete structures exposed to marine environments. Cement and Concrete Composites. 2008; 30(2):113-21.

6. Pu SY, Yuan SL, Fan ZG. Factors affecting corrosion and approaches for improving durability of ocean reinforced concrete structures. Ocean Engineering. 2004; 31(5-6):779-89.

7. Mosavi Amir A, Rudolf S, Sami R. Effect of temperature on daily modal variability of a steel-concrete composite bridge. J Bridge Eng. 2012; 7(6):979-83.

8. Lopez W, Gonzalez JA. Influence of the degree of pore saturation on the resistivity of concrete and the corrosion rate of steel reinforcement. Cement and Concrete Research. 1993; 23(2):368-76.

9. Huet B, L'hostis V, Santarini G, Feron D, Idrissi H. Steel corrosion in concrete: Determinist modelling of cathodic reaction as a function of water saturation degree. Corrosion Science. 2007; 49(4):1918-32.

10. Jiezhen H, Xuequn C, Xiaogang L, Peichang D, Gui W. The coupled effect of temperature and carbonation on the corrosion of rebars in the simulated concrete pore solutions. Journal of Chemistry. 2015: 1-6.

11. Enevoldsen JN, Hansson CM, Hope BB. The influence of internal relative humidity on the rate of corrosion of steel embedded in concrete and mortar. Cement and Concrete Research. 1994; 24(7):1373-82.

12. Abel C, Francisco C, Jose HJ, Tezozomoc P. Atmospheric corrosion of reinforced concrete steel in Tropical Coastal Regions. Engineering Journal. 2012; 17(2):1-18.

13. Hua JJ, Shu YY. Prediction model for the time-varying corrosion rate of rebar based on micro-environment in concrete. Construct Build Mater. 2012; 35:625-32.

14. Geng O, Yuan YS, Jiang JH. Time-varying model of steel corrosion in concrete. J Southeast Univ. 2010; 40(6):1293-7.

15. Anders L. Chloride ingress data from field and laboratory exposure - Influence of salinity and temperature. Cement and Concrete Composites. 2007; 29(2):88-93.

16. Tomasz J, Mariusz J. Influence of rapid changes of moisture content in concrete and temperature on corrosion rate of reinforcing steel. Procedia Engineering. 2015; 108:316-23.

17. Al-Gahtani AS. Effect of curing methods on the properties of plain and blended cement concretes. Construct Build Mater. 2010; 24(3):308-14.

18. Ramezanianpour AA, Malhotra VM. Effect of curing on the compressive strength, resistance to chloride-ion penetration and porosity of concretes incorporating slag, fly ash or silica fume. Cement and Concrete Composites. 1995; 17(2):125-33. 
19. Arafah A, Al-Zaid R, Al-Haddad M. Influence of nonstandard curing on the strength of concrete in arid areas. Cement and Concrete Research. 1996; 17(9):1341-50.

20. Taryal MS, Chowdhury MK, Matala S. The effect of practical curing methods used in Saudi Arabia on compressive strength of plain concrete. Cement and Concrete Research. 1986; 16(5):633-45.
21. Pech-Canul MA, Castro P. Corrosion measurements of steel reinforcement in concrete exposed to a tropical marine atmosphere. Cement and Concrete Research. 2002; 32(3):491-8.

22. Andrade C, Alanso C. Test methods for on-site corrosion rate measurement of steel reinforcement in concrete by means of the polarization resistance method. Materials and Structures. 2004; 37:623-43. 